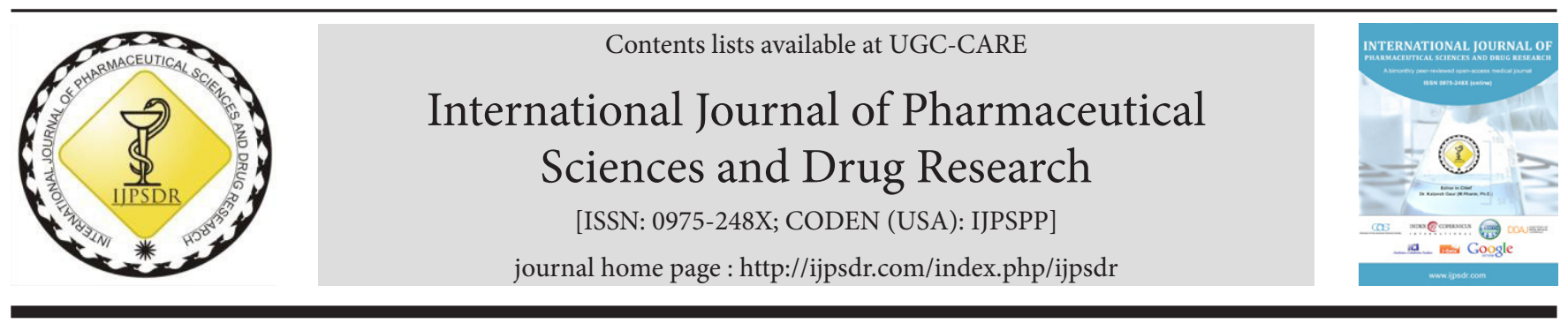

Research Article

\title{
Evaluation of In vitro Antioxidant and Cytotoxic Effect of Methanol Extract from Aerial parts of Myristica beddomei King ssp. ustulata W.J. de Wilde
}

\author{
Neethu Joy, Mahesh Mohan* \\ School of Environmental Sciences, Mahatma Gandhi University, Kottayam-686560, Kerala, India
}

\begin{tabular}{|c|c|}
\hline A RT I C L E I N F O & A B S T RAC T \\
\hline $\begin{array}{l}\text { Article history: } \\
\text { Received: } 07 \text { January, } 2019 \\
\text { Revised: } 29 \text { February, } 2020 \\
\text { Accepted: } 08 \text { March, } 2020 \\
\text { Published: } 30 \text { March, } 2020 \\
\text { Keywords: } \\
\text { Anticancer, DPPH radical } \\
\text { scavenging assay, } \\
\text { FRAP assay, Myristicaceae, } \\
\text { Phytochemistry, } \\
\text { Total antioxidant capacity. } \\
\text { DOI: } \\
\text { 10.25004/IJPSDR.2020.120204 }\end{array}$ & 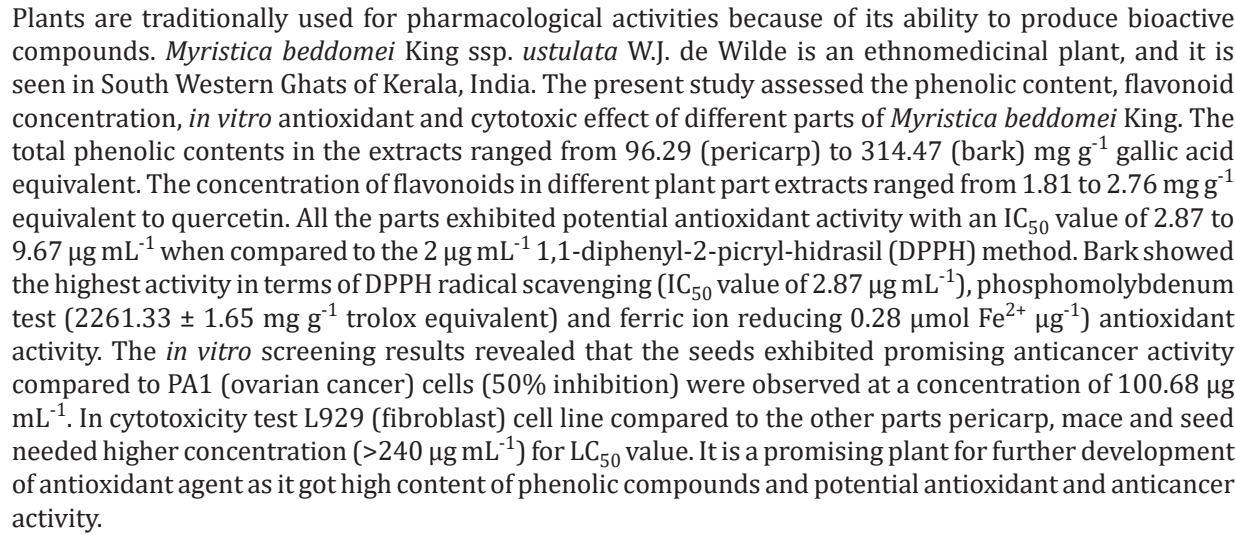 \\
\hline
\end{tabular}

\section{INTRODUCTION}

Nature has been a source of medicinal agents for thousands of years, and a large number of modern drugs have been isolated from natural sources based on their use in traditional medicine. ${ }^{[1-3]}$ In natural resources, plants are the good sources for the invention of pharmaceutical compounds and medicines. ${ }^{[4]}$ The medicinal property of plants is because of many phytochemicals with various bioactivities, including antioxidant, anti-inflammatory, and anticancer. ${ }^{[5,6]}$ Phytochemicals are highly varied in structure, and several compounds are aromatic substances like phenols or their oxygen-substituted derivatives. ${ }^{[7]}$ In nature, there are about eight thousand plant phenolics and which are seen in various plant parts both in a free state and as glycosides. All the phenolics are widely distributed as flavones and flavonols. ${ }^{[8]}$

Overproduction of oxidants in the human body is responsible for the pathogenesis of several human diseases, cardiovascular diseases, and aging. The scavenging of these oxidants is thought to be an effective measure to depress the level of oxidative stress of organisms. ${ }^{\text {[9] }}$ Plant-derived antioxidants have been products of choice in therapeutic formulations for their potent free radical scavenging activity and mitigating and curing illnesses and diseases associated with oxidative stress. ${ }^{[10]}$ Cytotoxicity studies are a useful initial step in determining the potential toxicity of biologically active compounds isolated from plants. ${ }^{[11]}$

\footnotetext{
*Corresponding Author: Dr. Mahesh Mohan

Address: School of Environmental Sciences, Mahatma Gandhi University, Kottayam-686560, Kerala, India

Email $\bowtie:$ maheshmohan@mgu.ac.in

Relevant conflicts of interest/financial disclosures: The authors declare that the research was conducted in the absence of any commercial or financial relationships that could be construed as a potential conflict of interest.

Copyright (C) 2020 Neethu Joy et al. This is an open access article distributed under the terms of the Creative Commons Attribution- NonCommercialShareAlike 4.0 International License which allows others to remix, tweak, and build upon the work non-commercially, as long as the author is credited and the new creations are licensed under the identical terms.
} 
Myristica beddomei King, an ethanomedicinal plant used by Malampandaram tribes of Kerala, is the wild relatives of nutmeg and mace. This tree belongs to the family Myristicaceae and is locally known as "Ponnampoo". Seed and pericarp of this species are used in traditional medicines. It is extensively utilized as a substituent or adulterant of nutmeg products in South India. ${ }^{[12-14]}$ There are very few reports on the phytochemistry and pharmacological activities of $M$. beddomei. ${ }^{[15,16]}$ The pericarp of Myristica beddomei ssp. ustulata was studied for its essential oil composition, total phenolic, anthocyanin, antioxidant, and nutritional analysis. It is reported that $\beta$-caryophyllene $(25.41 \%)$ is the most important constituent of pericarp essential oil. ${ }^{[15]}$ The quantitative determination of bioactive compounds of Myristica beddomei King fruit was reported and its in vitro antiproliferative activity was studied. ${ }^{[16]}$ The present study aims to determine the phenolic content, flavonoid concentration, antioxidant, and in vitro cytotoxic effect of methanol extract of different parts like bark, leaf, pericarp, mace, and seed of $M$. beddomei King ssp. ustulata W.J. de Wilde.

\section{MATERIALS AND METHODS}

\section{Plant material and Preparation of Extract}

Bark, leaf, pericarp, mace, and seed of $M$. beddomei King ssp ustulata W.J. de Wilde. (Figs. 1 and 2) were collected from Achenkovil forest, Kerala. The plant was identified with the help of Dr. N. Sasidharan, and a voucher specimen was deposited at Kerala Forest Research Institute, Thrissur (MGU NJ-01). The samples were shade dried, powdered, and sieved into a fine powder and packed in a sealed plastic bottle until extraction. Total $20 \mathrm{~g}$ of dried powdered sample was extracted with $250 \mathrm{~mL}$ methanol using a Soxhlet apparatus. The extract concentrated by using a Rotary vaccum evaporator.

\section{Determination of Total Phenol Content}

Total phenolic content was estimated by Folin Ciocalteu's spectrophotometric method and is expressed as $\mathrm{mg} \mathrm{g}^{-1}$ of gallic acid equivalent (GAE). ${ }^{[17-19]}$

\section{Determination of Total Flavonoid Content}

Total flavonoid content was measured with aluminium chloride colorimetric assay. The total flavonoids are expressed as $\mathrm{mg} \mathrm{g}^{-1}$ of quercetin equivalent (QE). ${ }^{[17,19,20-22]}$

\section{Antioxidant Properties}

\section{DPPH Radical Scavenging Method}

The antioxidant activity was determined with 1 , 1-diphenyl-2-picril-hydrazyl assay. ${ }^{[23]}$ A $0.1 \mathrm{mM}$ solution of DPPH and $1 \mathrm{~mL}$ of this was added to $3 \mathrm{~mL}$ of different extracts in ethanol at different concentrations $(10,20$, $40,60,80$, and $100 \mu \mathrm{g} \mathrm{mL}^{-1}$ ). The mixture was shaken vigorously and allowed to stand at room temp for 30 minutes. The absorbance was measured at $517 \mathrm{~nm}$ by using a spectrophotometer (UV-VIS Shimadzu). The standard compound being used was ascorbic acid. The $\mathrm{IC}_{50}$ value of the sample, which is the concentration of sample required to inhibit $50 \%$ of the DPPH free radical, was calculated. Lower absorbance of the reaction mixture indicated higher free radical activity. The percent DPPH scavenging effect was calculated by using following equation:

The DPPH scavenging effect (\%) or percent inhibition

$$
=\mathrm{A} 0-\mathrm{A} 1 / \mathrm{A} 0 \times 100 \text {. }
$$

Where $\mathrm{A} 0$ was the absorbance of control reaction, and A1 was the absorbance in the presence of test or standard sample.

\section{Total Antioxidant Capacity (TAC)}

The total antioxidant capacity (TAC) of plant extracts was determined spectrophotometrically by the phosphomolybdenum assay. ${ }^{[24]} 15 \mu \mathrm{L}$ of a $10 \mathrm{mg} \mathrm{mL}^{-1}$ extract solution in methanol was mixed with $3 \mathrm{~mL}$ phosphomolybdenum reagent ( $28 \mathrm{mM}$ sodium phosphate and $4 \mathrm{mM}$ ammonium molybdate in $0.6 \mathrm{M}$ sulphuric acid) in test tubes. Incubation was then carried out for $90 \mathrm{~min}$ in a water bath at $95^{\circ} \mathrm{C}$. After cooling to room temperature,

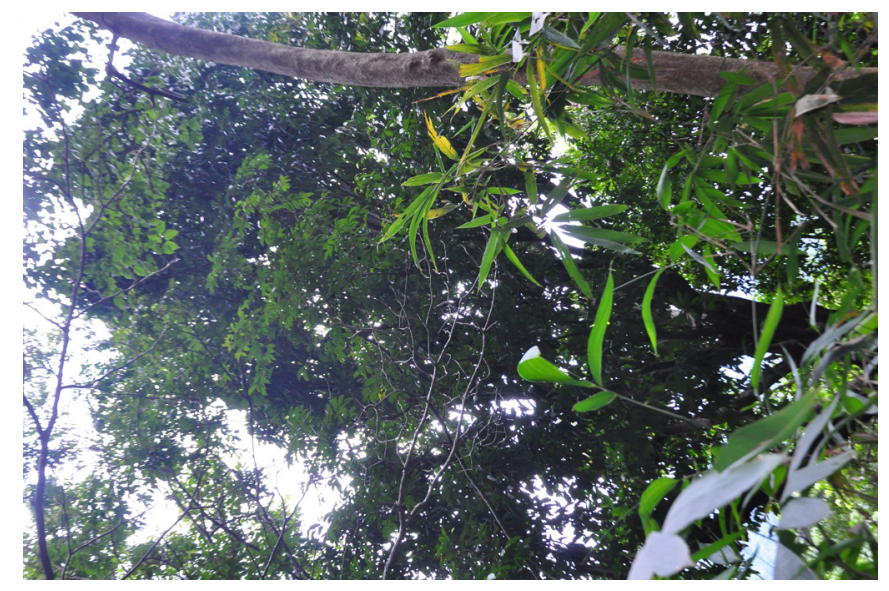

Fig. 1: M. beddomei King ssp. ustulata W.J. de Wilde Habit.

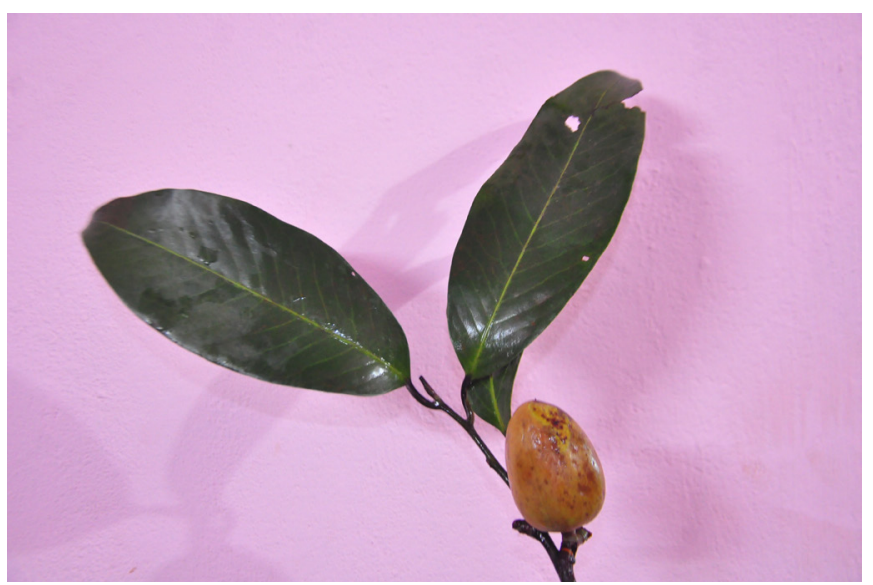

Fig. 2: Twig with fruit and leaf 
Evaluation of in vitro Antioxidant and Cytotoxic Effect of Methanol Extract from aerial parts of Myristica beddomei King ...

the absorbance of the solutions was measured using a UV-visible spectrophotometer at $695 \mathrm{~nm}$ against a blank. TAC results were expressed as trolox equivalents $\left(\mathrm{mg} \mathrm{g}^{-1}\right.$ of trolox equivalent sample).

\section{Ferric Reducing Antioxidant Power (FRAP) Assay}

The ferric reducing activity of the plant extracts was determined using ferric, reducing antioxidant power (FRAP) of Benzie and Strain. ${ }^{[25]}$ Freshly prepared FRAP reagent $(3.0 \mathrm{~mL})$ was warmed at $37^{\circ} \mathrm{C}$ and mixed with the extract in different concentrations. The reaction mixtures were later incubated at $37^{\circ} \mathrm{C}$ for up to $15 \mathrm{~min}$ and absorbance recorded at $593 \mathrm{~nm}$.

\section{In vitro Cytotoxic Effect}

L929 (fibroblast) cells and PA1 (ovarian cancer) cells were used in this study. The cells were procured from National Centre for Cell Sciences (NCCS), Pune, India, and maintained Dulbecco's modified Eagle's medium, DMEM (Sigma Aldrich, USA). $100 \mu \mathrm{L}$ cell suspension (5x104 cells well $^{-1}$ ) was seeded in 96 well tissue culture plates and incubated at $37^{\circ} \mathrm{C}$ in a humidified $5 \% \mathrm{CO}_{2}$ incubator. A $1 \mathrm{mg}$ of the in $1 \mathrm{~mL}$ DMEM using a cyclomixer. After 24 hours the growth medium was removed, freshly prepared each compound in 5\% DMEM were five times serially diluted by two-fold dilution $(100,50,25,12.5 \mu \mathrm{g}, 500 \mu \mathrm{L}$ of DMEM) and each concentration of $100 \mu \mathrm{L}$ was added. Non treated control cells were also maintained. The entire plate was observed after 24 hours of treatment in an inverted phasecontrast tissue culture microscope (Olympus CKX41 with Optika Pro5 CCD camera). Fifteen mg of MTT (Sigma, M-5655) was reconstituted in $3 \mathrm{~mL}$ phosphate-buffered saline PBS until completely dissolved and sterilized by filter sterilization. After 24 hours of the incubation period, the sample content in wells was removed, and $30 \mu \mathrm{L}$ of reconstituted MTT solution was added to all test and cell control wells, then incubated for 4 hours. After the incubation period, the supernatant was removed, and $100 \mu \mathrm{l}$ of MTT Solubilization solution was added. The absorbance values were measured by using a microplate reader at a wavelength of $540 \mathrm{~nm}$, and the percentage of growth inhibition was calculated. ${ }^{[26]}$

\section{Statistical Analysis}

All the assays were performed in triplicate (unless stated otherwise), and the data points are expressed as mean \pm SD. The statistical significance of the differences was determined by a one-way analysis of variance (ANOVA) followed by the post-hoc Tukey test ( $p<0.05$ ). The correlation coefficient (R) between the total phenolics as well as flavonoids and the antioxidant activity was also carried out using the SPSS v20.0.

\section{RESULTS}

Methanol extracts of different parts such as bark, leaf, pericarp, mace, and seed were used to examine the total phenolic content, flavonoid concentration, and antioxidant activity. The percentage yield of different parts of methanol plant extract was presented in Table 1. The highest yield of solid residue was obtained in mace (36\%). Red, yellowish-green, reddish-black, dark yellow, and yellowish red residues were obtained for bark, leaf, pericarp, seed, and mace, respectively. The methanol extracts of bark, leaf, and pericarp were smooth, whereas seed and mace extracts were little gummy in nature.

The total phenolic contents were ranged from 96.30 to $314.47 \mathrm{mg} \mathrm{GAE} \mathrm{g}^{-1}$. The highest concentration of phenols was measured in bark (314.47 \pm 0.49 ), whereas pericarp contains smallest concentration of phenols (96.30 \pm 2.71). The total phenolic content has significantly varied $(\mathrm{p}<0.05)$ among the plant parts. The concentration of flavonoids in plant extracts from $M$. beddomei ranged from 1.81-2.77 mg QE g ${ }^{-1}$. Mace contains the highest flavonoid concentration $(2.77 \pm 0.01)$, and the lowest was found in bark (1.81 \pm 0.01$)$ compared to other parts (Table 1 ).

\section{Antioxidant Activity}

The DPPH radical scavenging activity of $M$. beddomei extracts and standard ascorbic acid were assessed and expressed in terms of $\mathrm{IC}_{50}$ value. All the parts exhibited potential antioxidant activity, and the $\mathrm{IC}_{50}$ value was ranged from 2.87 to $9.67 \mu \mathrm{g} \mathrm{mL}^{-1}$ compared with standard ascorbic acid $\left(\mathrm{IC}_{50}\right.$ value $\left.2.38 \mu \mathrm{g} \mathrm{mL}^{-1}\right)$. The $\mathrm{IC}_{50}$ value for ascorbic acid was $2.38 \pm 0.028 \mu \mathrm{g} \mathrm{mL}^{-1}$ (Table 2).

The total antioxidant capacity of different parts of Myristica beddomei was in the order of bark > leaf $>$ seed $>$ mace> pericarp (Table 2). The bark (2261.33 $\pm 1.65 \mathrm{mg} \mathrm{g}^{-1}$ trolox equivalent) showed high antioxidant capacity followed by the leaf (1208 $\pm 0.70 \mathrm{mg} \mathrm{g}^{-1}$ trolox equivalent). TAC and FRAP reducing power has showed similar pattern of DPPH radical scavenging activity, i.e., bark exhibited

Table 1: Extractive value, total phenol, and total flavonoid concentration of different parts of Myristica beddomei King ssp. ustulata W.J. de Wilde

\begin{tabular}{|c|c|c|c|}
\hline & Extractive value $\left(\% w w^{-1}\right)$ & Total phenol (mg GAE $\left.g^{-1}\right)$ & Total flavonoid ( $m g Q E g^{-1}$ ) \\
\hline Bark & 24.7 & $314.47 \pm 0.49$ & $1.81 \pm 0.01$ \\
\hline Leaf & 21.8 & $246.82 \pm 3.07$ & $2.08 \pm 0.04$ \\
\hline Pericarp & 14.5 & $96.30 \pm 2.71$ & $2.57 \pm 0.03$ \\
\hline Mace & 36 & $127.86 \pm 3.20$ & $2.77 \pm 0.01$ \\
\hline Seed & 27.4 & $102.86 \pm 0.43$ & $2.33 \pm 0.02$ \\
\hline
\end{tabular}


Neethu Joy et al.

Table 2: Antioxidant activities of different parts of Myristica beddomei King ssp. ustulata W.J. de Wilde

\begin{tabular}{lllllll}
\hline Antioxidant activity & Ascorbic acid & Bark & Leaf & Pericarp & Mace & Seed \\
\hline DPPH IC $_{50}\left(\mu \mathrm{g} \mathrm{ml}^{-1}\right)$ & $2.38 \pm 0.028$ & $2.87 \pm 0.042$ & $4.51 \pm 0.028$ & $9.665 \pm 0.077$ & $6.175 \pm 0.007$ & $6.54 \pm 0.014$ \\
TAC mg TE g & & $2261.33 \pm 1.65$ & $1208 \pm 0.70$ & $374.66 \pm 1.69$ & $556 \pm 0.57$ & $1148 \pm 1.41$ \\
FRAP $\mu \mathrm{mol} \mathrm{Fe}^{2+} \mu \mathrm{g}^{-1}$ & & $113.1 \pm 0.28$ & $99.9 \pm 1.97$ & $21.88 \pm 2.86$ & $43.025 \pm 1.59$ & $57.9 \pm 1.69$ \\
\hline
\end{tabular}

Table 3: Correlation between phenolic content, flavonoid content and antioxidant activities of different parts of $M$. beddomei King ssp. ustulata W.J. de Wilde

\begin{tabular}{lllll}
\hline & Phenol & Flavanoid & DPPH & TAC \\
\hline Flavanoid & -.299 & - & - & - \\
DPPH & -.409 & $.753^{* *}$ & - & - \\
TAC & 094 & $-.918^{* *}$ & $-.869^{* *}$ & - \\
FRAP & $.549^{*}$ & $-.794^{* *}$ & $-.957^{* *}$ & $.824^{* *}$ \\
\hline
\end{tabular}

*Correlation is significant at the 0.05 level (2-tailed).

**Correlation is significant at the 0.01 level (2-tailed).

Table 4: The $\mathrm{LC}_{50}\left(\mu \mathrm{g} \mathrm{mL}{ }^{-1}\right)$ values of different parts of M. beddomei King ssp. ustulata W.J. de Wilde methanolic extract to the cell line L929 and PA1

\begin{tabular}{llllll}
\hline Cell lines & Bark & Leaf & Pericarp & Mace & Seed \\
\hline L929 & 221.99 & 250.85 & 257.99 & 254.51 & 245.55 \\
PA1 & 238.07 & 224.58 & 152.92 & 123.4 & 100.68 \\
\hline
\end{tabular}

significantly $(p>0.05)$ higher activity $(113.1 \pm 0.28 \mu \mathrm{mol}$ $\left.\mathrm{Fe}^{2+} \mu \mathrm{g}^{-1}\right)$ and followed by leaf and other aerial parts (Table 2). FRAP, phosphomolybdenum assay, and DPPH assay have indicated the high antioxidant capacity of bark. Pericarp has shown low antioxidant capacity compared to other parts. The tested antioxidant assays were significantly different $(p<0.05)$ among the plant parts.

Correlation analysis was carried out to understand the relationship between phytochemicals and bioactivity and is presented in Table 3. The correlation table reveals that DPPH radical scavenging activity, total antioxidant activity by phosphomolybdenum method, and FRAP reducing power potential showed significant $(p<0.05)$ correlation with total flavonoid content. FRAP value was correlated with phenolic content. The DPPH radical scavenging activity has shown a significant correlation with total antioxidant activity by phosphomolybdenum method and FRAP assay.

\section{Cytotoxic Activity}

The cytotoxic activity of methanol extracts of different parts M. beddomei on L929 (fibroblast) and PA1 (ovarian cancer) cells was investigated in vitro using standard 3-(4) 5-Dimethyl-thiazol-Zyl)-2, 5 diphenyl tetrazolium bromide (MTT assay). The different cell lines were treated with increasing concentrations $\left(6.25-100 \mu \mathrm{g} \mathrm{mL}^{-1}\right)$. The result showed decreased cell viability and cell growth inhibition and is in a dose-dependent manner (Fig. 3). The respective $\mathrm{LC}_{50}$ values were calculated and presented in Table 4 . The inhibitory concentration $\left(\mathrm{LC}_{50}\right)$ value was calculated by the test sample of concentration at which $50 \%$ of cells viable and calculated from the logarithmic trend line of the cytotoxicity graphs. The in vitro screening results revealed that the seeds exhibited promising anticancer activity compared in PA1 cells (50\% inhibition) were observed at a concentration of $100.68 \mu \mathrm{g} \mathrm{mL}^{-1}$. This inhibition at the mentioned concentration indicates a greater potency of compound present in the seed with a strong lethal effect over cancer (PA1) cell line compared with other parts. Bark and leaf have low inhibitory activity against PA1 cell line. The $\mathrm{LC}_{50}$ value for the $\mathrm{L} 929$ cell line of pericarp was high $\left(257.99 \mu \mathrm{g} \mathrm{mL}^{-1}\right)$, whereas it was low for bark $\left(221.99 \mu \mathrm{g} \mathrm{m}^{-1}\right)$ among the various parts of $M$. beddomei.

\section{DISCUSSION}

Free radicals are generated normally in cells during metabolic processes. Examples of these radicals include DPPH, hydrogen peroxide, hydroxyl, superoxide anions, and nitric oxide radicals. Excess generation of free radicals can destroy the immune system and develop a wide range of diseases. ${ }^{[27-29]}$ To minimize the complications generated by free radicals, the intake of antioxidants might be very beneficial. Antioxidant produces its effect either by protecting the antioxidant defense mechanisms or scavenging the reactive oxygen species (ROS). ${ }^{[29,30]}$ In this study, three methods, including DPPH, ferric reducing power, and total antioxidant capacity assays, were used for testing antioxidant activity. In the DPPH method, the antioxidant activity was found to increases with an increase of concentration of plant part extracts, and lower $\mathrm{IC}_{50}$ value results in better protective action. ${ }^{[31]}$ DPPH is nitrogen-centered free radical, accepting hydrogen from the antioxidants present in the plant extract, DPPH is converted into a stable molecule, diphenyl-picryl hydrazine. ${ }^{[32,33]}$ The observed reduction of DPPH by the extract was either due to the transfer of a hydrogen atom or the transfer of an electron. Phosphomolibdinum assay is based on the reduction of phosphomolybdate ion in the presence of an antioxidant resulting in the formation of a green phosphate complex, 
a

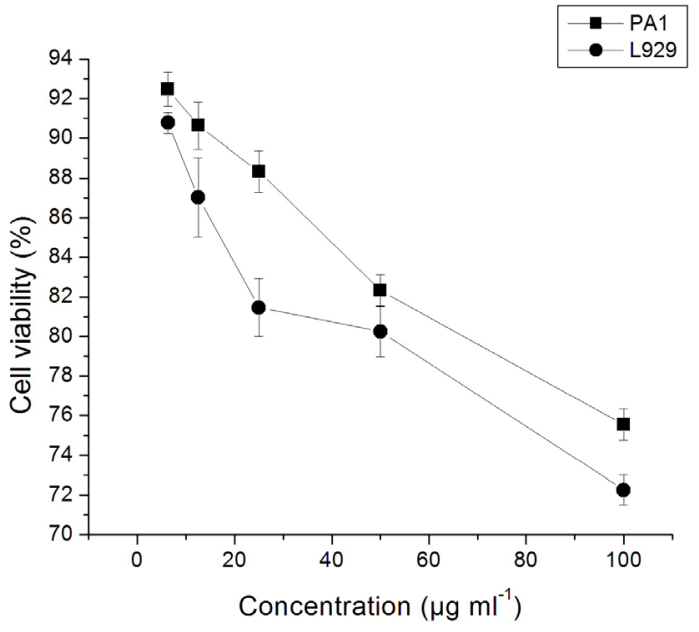

C

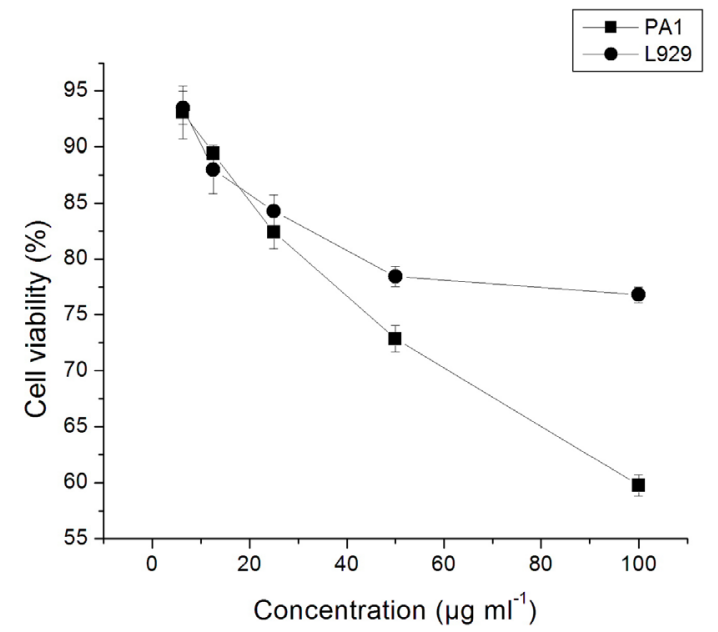

b

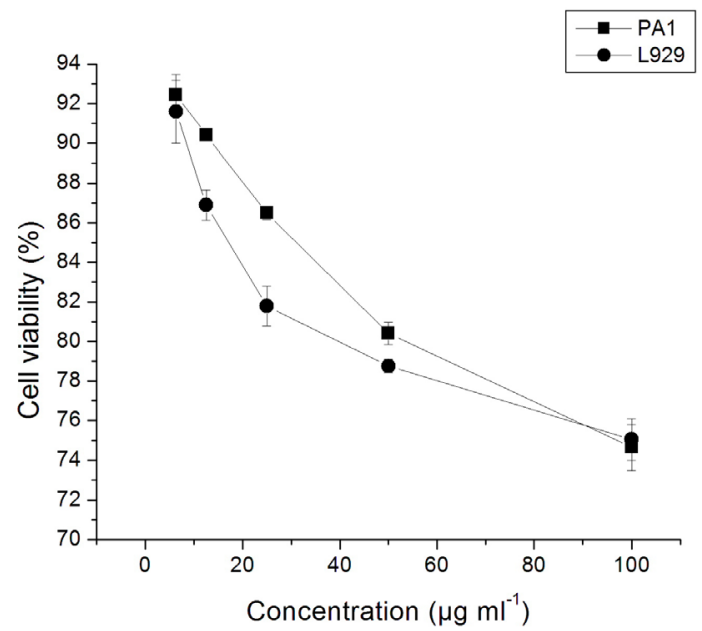

d

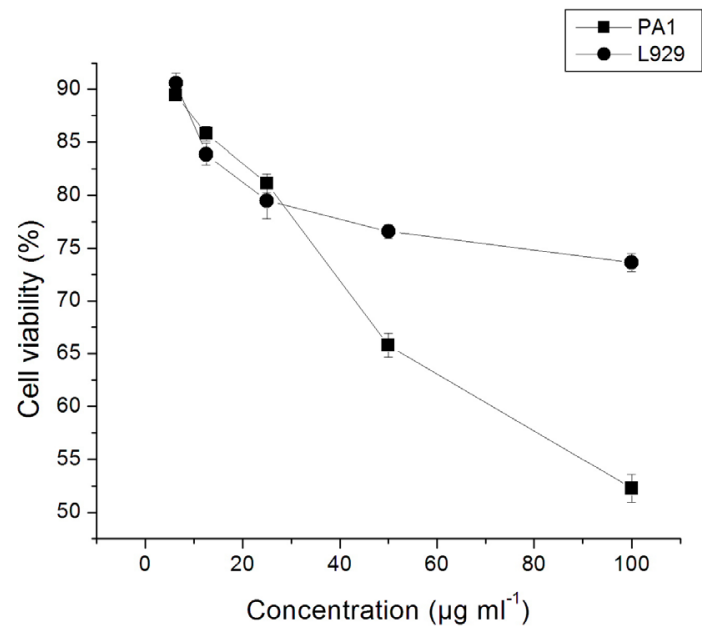

$\mathrm{e}$

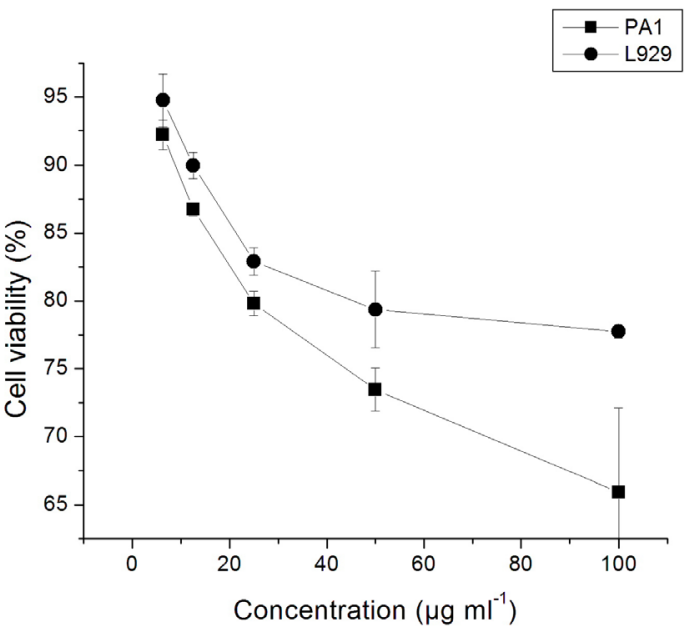

Fig. 3: Cell viability of methanol extract of M.beddomei plant parts (a) Bark; (b) Leaf; (c) Pericarp; (d) Mace; (e) Seed

which is measured spectrophotometrically (Knezevic et al. 2011). The FRAP assay was based on the ability to reduce the ferric 2,4,6-tripyridyl-s-triazine complex $\left(\mathrm{Fe}^{3+}\right.$ - TPTZ) to provided blue colored ferrous complex $\left(\mathrm{Fe}^{2+}-\mathrm{TPTZ}\right)$ in acidic medium at $593 \mathrm{~nm}$ absorbance. This method is fast, reproducible, and non-specific. ${ }^{[34]}$
The present study indicated that the antioxidant activity is high for the bark extracts with high total phenolic content. Earlier studies were also showed the same trend as the phenols having free radical scavenging ability which is facilitated by their hydroxyl groups. Hence, literature suggests that the content of phenolic compounds could 
be used as a basis for rapid screening of antioxidant activity. ${ }^{[16,35]}$ Flavonoids, including flavones, flavanols, and condensed tannins, also indicate the antioxidant activity. ${ }^{[35]}$

Murcia et al. ${ }^{[36]}$ reported that the antioxidant activity of nutmeg extract is due to the presence of phenylpropanoid compounds. The aril part of $M$. fragrans has significant antioxidant activity due to its ability to inhibit lipid peroxidation ${ }^{[37]}$ and superoxide radical scavenging activity in rat. ${ }^{[38]}$ The methanolic extract of the pericarp of Myristica beddomei ssp. ustulata has shown a large amount of phenols and polyphenols. The pericarp extract also showed high antioxidant activity due to the presence of a higher amount of polyphenolic compounds. ${ }^{[15]}$ The DPPH test with spice Myristica malabarica (rampatri) revealed the methanol extract showed the best antioxidant activity compared with ether and aqueous extracts. The study reports 2-acylresorcinol and four known diarylnonanoids of which the diarylnonanoid, malabaricone $C$, showed the maximum DPPH scavenging activity. ${ }^{[12]}$ The present study showed a strong positive correlation between antioxidant activities and total phenolic content, and these findings are in agreement with earlier studies. ${ }^{[39,40]}$

$M$. beddomei has shown antiproliferative activity against human cancer cell lines A549, DLD-1, DU145, FaDu, and MCF-7 too. ${ }^{[14]}$ An earlier study has shown the highest antiproliferative activity with $>96 \%$ growth inhibition was found for the extracts of pericarp and seed of M. beddomei at $100 \mu \mathrm{g} \mathrm{mL}^{-1}$ concentration. However, in the present study $>200 \mu \mathrm{g} \mathrm{mL}^{-1}$ has been required for $50 \%$ of inhibition of L929 cell line. This may be due to the general fact that high concentration is needed for the inhibition of normal cells compared to cancer-causing cell lines.

\section{CONCLUSION}

The result of this study demonstrates that different parts of $M$. beddomei extracts in methanol were screened for antioxidant, anticancer activities. The extract of various parts of $M$. beddomei has high phenolic and flavonoid content, and the bark shown maximum antioxidant activity. It was found that the methanol extract of $M$. beddomei has maximum antioxidant activity, and methanol extract of seed showed promising activity against the PA1 cancer cell line. Bark has shown high antioxidant activity in phosphomolybdenum assay, FRAP, and DPPH assay. A strong correlation was noticed between total flavonoid content and antioxidant activity observed in various assays. FRAP value was also correlated with phenolic content. The present study concludes that the methanol extract of $M$. beddomei has a high concentration of phenolic compounds and flavonoids, and their antioxidant activity was also high. Hence the plants has high potential value for drug preparation. The current investigation of antioxidant and anticancer activities was evaluated using in vitro experiments only, and further investigation for a mechanism of action and in vivo experiments will lead to a complete assessment of $M$. beddomei plant parts.

\section{ACKNOWLEDGMENT}

We would like to thank Kerala State Biodiversity Board, for the financial support to the first author. Authors also acknowledge KSCSTE-SARD, DST-PURSE, DST-FIST for the financial support given for instrumentation facility.

\section{REFERENCES}

1. Balick JM, Cox PA. Plants, people, and culture: The science of ethnobotany. Scientific American Library New York, 1996, pp 1-24.

2. Gurib-Fakim A. Medicinal plants: traditions of yesterday and drugs of tomorrow. Mol. Asp. Med. 2006;27:1-93.

3. Ahamed SK, Hassan M, Imam M, Abeer U, Ahmed I. Chemical group characterization and biological investigation of Spermacoce latifolia. Int. J. Biol. Pharm. Res. 2013;4:194-199.

4. Makkar HPS, Norvsambuu T, Lkhagvatseren S, Becker K. Plant secondary metabolites in some medicinal plants of Mongolia used for enhancing animal health and production. Tropicultura. 2009; 27:159-167.

5. Wu JY, Yang BB. Anticancer activity of Hemsya amabitis extract. Life. Sci. 2002;71:2161-2170.

6. Samatha T, Shyamsundarachary R, Srinivas P, Swamy NR. Quantification of total phenolic and total flavonoid contents in extracts of Oroxylum indicum l.kurz. Asian. J. Pharm. Clin. Res. 2012;5:77-179.

7. Neelavathi P, Venkatalakshmi P, Brindha P. Antibacterial activities of aqueous and ethanolic extracts of Terminalia catappa leaves and bark against some pathogenic bacteria. Int. J. Pharm. Pharm. Sci. 2013;5:114-120.

8. John B, Sulaiman CT, George S, Reddy VRK. Total phenolics and flavonoids in selected medicinal plants from Kerala. Int. J. Pharm. Pharm. Sci. 2014;6:406-408.

9. Zhang Y, Gan R, Li S, Zhou Y, Li A, Xu D. Antioxidant phytochemicals for the prevention and treatment of chronic diseases. Molecules. 2015;20:21138-21156.

10. Al-Qudah MA, Obeidat SM, Muhaidat R, Al-Trad B, Al-Jaber HI, Lahham JN. Intercomparative investigation of the total phenols, total flavonoids, In vitro and In vivo antioxidant activities of Capparis cartilaginea (Decne.) maire and weiller and Capparis Ovata Desf. Pharm. Mag. 2018;14:154-160.

11. Mcgaw, LJ., Elgorashi EE, Eloff JN. Cytotoxicity of african medicinal plants against normal animal and human Cells. Toxicological survey of African medicinal plants Elsevier, London, 2014.

12. Patro, BS, Bauri AK, Mishra S, Chattopadhyay S. Antioxidant activity of Myristica malabarica extracts and their constituents. J. Agric. Food. Chem. 2005; 53:6912-6918.

13. Zachariah TJ, Leela NK, Maya KM, Rema J, Mathew PA, Vipin TM, et al. Chemical composition of leaf oils of Myristica beddomei (King), Myristica fragrans (Houtt.) and Myristica malabarica (Lamk.). J. Spices. Aromat. Crop. 2008;17:10-15.

14. Pandey R, Mahar R, Hasanain M, Shukla SK, Sarkar J. Rapid screening and quantitative determination of bioactive compounds from fruit extracts of Myristica species and there in vitro antiprolife-rative activity. Food. Chem. 2016;211:483-493.

15. Vidhya B, Venkatesh PT. Essential oil composition, antioxidant, and nutritional properties of fruit pericarp of Myristica beddomei King ssp . ustulata de Wilde-an endangered tree species. Anal. Chem. Let. 2015;5:21-30.

16. Dudhe SP. Phytochemical screening of selected plant species related to cosmetics. Int. J. Adv. Res. Innov. Ideas. Educ. 2017;3:32163220.

17. Patel A, Patel A, Patel A, Patel NM. Estimation of flavonoid, polyphenolic content, and in vitro antioxidant capacity of leaves of 
Evaluation of in vitro Antioxidant and Cytotoxic Effect of Methanol Extract from aerial parts of Myristica beddomei King ...

Tephrosia purpurea Linn. (Leguminosae). Int. J. Pharma. Sci. Res. 2008;1:66-77.

18. Bhalodia N, Nariya PR, Acharya Shukla VE.Valuation of in vitro antioxidant activity of flowers of Cassia fistula Linn. Int. J. Pharmtech. Res. 2011;3:589-599.

19. Kamtekar S, Keer V, Patil V. Estimation of phenolic content, flavonoid content, antioxidant and alpha amylase inhibitory activity of marketed polyherbal formulation. J. Appl. Pharm. Sci. 2014; 4:61-65.

20. Satish Kumar T, Baskar R, Shanmugam S, Rajasekaren P, Sadasivam $\mathrm{S}$, Manikandan V. Optimization of flavonoids extraction from the leaves of Tabernaemontana Heyneana Wall. Using L16 orthodesign. Nat. Sci. 2008;6:10-21.

21. Patel S, Patl J, Patel RK. To study proximate analysis \& biological evaluation of Triphala Guggulu formulation. Int. J. Pharm. Tech. Res. 2012;4:1520-1526

22. Pallab K, Tapan B, Tapas P, Ramen K. Estimation of total flavonoids content (TPC) and antioxidant activities of methanolic whole plant extract of Biophytum sensitivum Linn. J. Drug. Delv. Ther. 2013;3:33-37.

23. Aquino R, Morelli S, Lauro MR, Abdo S, Saija A, Tomaino A. Phenolic constituents and antioxidant activity of an extract of Anthurium versicolor Leaves. J. Nat. Prod. 2001;64:1019-1023.

24. Phatak RS, Hendre AS. Total antioxidant capacity (TAC) of fresh leaves of Kalanchoe pinnata. J. Pharm. Phy tochem. 2014;2:32-35

25. Benzie IFF, Strain JJ. The ferric reducing ability of plasma (FRAP) as a measure of "Antioxidant Power": The FRAP Assay. Anal. Biochem. 1996;239:70-76.

26. Talarico LB, Zibetti RGM, Faria PCS, Scolaro LA, Duarte MER, Noseda MD, et al. Anti-herpes simplex virus activity of sulfated galactans from the red seaweeds Gymnogongrus griffithsiae and Cryptonemia crenulata. Int. J. Biol. Macromol. 2004;34:63-71.

27. Nigri GR, Kossodo $S$, Waterman P. Free radical attenuation prevents thrombosis and enables photochemical inhibition of vein graft intimal hyperplasia. J. Vasc. Surg. 2004; 39:843-849.

28. Schetter AJ, Heegaard NHH, Harris CC. Inflammation and cancer: interweaving microRNA, free radical, cytokine and p53 pathways. Carcinogenesis. 2009; 31:37-49.

29. Adnan, Chy NU, Rudra S, Tahamina A, Das R, Tanim MAH, etal. Evaluation of Bonamia semidigyna (Roxb.) for antioxidant, antibacterial, anthelmintic and cytotoxic properties with the involvement of polyphenols. Orient. Pharm. Exp. Med. 2018;19: 187-199. DOI: https://doi.org/10.1007/s13596-018-0334-x

30. Saeed N, Khan MR, Shabbir M. Antioxidant activity, total phenolic and total flavonoid contents of whole plant extracts Torilis leptophylla L. BMC Complement. Altern. Med. 2012;12:1174.

31. Kiranmayi GV, Ravishankar N, Rajendra Prasad KY. Comparative in vitro antioxidant activities of ethanolic extract, ethyl acetate extract (eae), and hexane extracts (he) of Tecoma gaudichaudi flowers. Int. J. Green. Pharm. 2018;12:S214-S2019.

32. Knezevic SV, Blazekovic B, Stefan MB, Alegro A, Koszegi T, Petrik J. Antioxidant activities and polyphenolic contents of three selected Micromeria species from Croatia. Molecules. 2011;16:1454-1470.

33. Saha S, Verma RJ, Saha S, Verma RJ. Antioxidant activity of polyphenolic extracts of Terminalia chebula Retzius fruits. J. Taibah. Univ. Sci. 2018;10:805-812.

34. Choirunnisa AR, Fidrianny I, Ruslan K. Comparison of five antioxidant assays for estimating antioxidant capacity from three solanum sp. Extracts. Asian. J. Pharm. Clin. Res. 2016;9:123-128.

35. Baba SA, Malik SA. Determination of total phenolic and flavonoid content, antimicrobial and antioxidant activity of a root extract of Arisaema jacquemontii Blume. J. Taibah. Univ. Sci. 2018;9:449-454.

36. Murcia MA, Egea I, Romojaro F, Parras P, Jimenez AM, Martinez-Tome M. Antioxidant evaluation in dessert spices compared with common food additives. Influence of irradiation procedure. J. Agric. Food. Chem. 2004; 52:1872-1881.

37. Yadav AS, Bhatnagar D. Modulatory effect of spice extracts on ironinduced lipid peroxidation in rat liver. Biofactors. 2007; 29:147-157.

38. Jose H, Arya KR, Sindhu TJ, Syamjith P, Vinod KR, Sandhya SA Descriptive review on Myristica fragrans Houtt. Hygeia. J. Drugs. Med. 2016;8:35-43.

39. Lizcano LJ, Bakkali F, Ruiz-Larrea MB, Ruiz-Sanz JI. Antioxidant activity and polyphenol content of aqueous extracts from Colombian Amazonian plants with medicinal use. Food. Chem. 2010;119:1566-1570.

40. Arumugam R, Kirkan B, Sarikurkcu. Phenolic profile, antioxidant and enzyme inhibitory potential of methanolic extracts from different parts of Astragalus ponticus Pall. South. Afr. J. Bot. 2019; $120: 268-273$

HOW TO CITE THIS ARTICLE: Joy N, Mohan M. Evaluation of in vitro Antioxidant and Cytotoxic Effect of Methanol Extract from aerial parts of Myristica beddomei King ssp. ustulata W.J. de Wilde. Int. J. Pharm. Sci. Drug Res. 2020; 12(2): 115-121. DOI: 10.25004/IJPSDR.2020.120204 